\title{
Knowledge on American Heart Association Guidelines Update for Cardiopulmonary Resuscitation among the Nurses Working at University Hospital, Kavre Shrestha $S,{ }^{1}$ Shrestha $R,{ }^{1}$ Karmacharya RM, ${ }^{2}$ Ranjit $S^{3}$
}

\author{
${ }^{1}$ Department of Nursing \\ ${ }^{2}$ Department of Surgery, \\ ${ }^{3}$ Department of Anesthesiology,
}

Dhulikhel Hospital, Kathmandu University Hospital, Kathmandu University School of Medical Sciences, Dhulikhel, Kavre, Nepal.

\section{Corresponding Author}

Sulekha Shrestha

Department of Nursing,

Dhulikhel Hospital, Kathmandu University Hospital,

Kathmandu University School of Medical Sciences,

Dhulikhel, Kavre, Nepal.

E-mail: sulekhastha@gmail.com

\section{Citation}

Shrestha S, Shrestha R, Karmacharya RM, Ranjit S. Knowledge on American Heart Association Guidelines Update for Cardiopulmonary Resuscitation among the Nurses Working at University Hospital, Kavre. Kathmandu Univ Med J. Online First.

\section{ABSTRACT}

\section{Background}

Cardiopulmonary resuscitation is the foundational technique for the emergency treatment of cardiac arrest and the standardized training of it has been emphasized more than ever. Competence of the nurses in this lifesaving procedure is a critical factor in patient outcome from cardiac arrest and can largely prevent sudden death.

\section{Objective}

Many evidences suggest lack of knowledge on proper cardiopulmonary resuscitation among nurses so the aim of this study was to assess the knowledge on 2015 American Heart Association guidelines update for cardiopulmonary resuscitation among nurses working at University hospital and to identify the relationship between the level of knowledge and selected variables.

\section{Method}

Two hundred and sixty nurses working in Dhulikhel hospital participated in the study. A cross-sectional descriptive study was conducted using a predesigned questionnaire based on 2015 guidelines updates for cardiopulmonary resuscitation that incorporated total of 20 questions.

\section{Result}

Total 260 participated in the study and all were female. Only one third of the nurses had good knowledge regarding 2015 guidelines update for cardiopulmonary resuscitation. No significant results existed between the knowledge score and age of the nurses, duration of work experience. However, significant results existed between the knowledge score and qualification, designation of the nurses and previous training on cardiopulmonary resuscitation.

\section{Conclusion}

One third of the nurses had good knowledge regarding 2015 guidelines update for cardiopulmonary resuscitation in this study. Thus, knowledge and practical approach has to be updated with current guidelines in cardiopulmonary resuscitation in order to improve the safety and effectiveness of patient care.

\section{KEY WORDS}

American heart association, Cardiopulmonary resuscitation, Knowledge 


\section{INTRODUCTION}

Cardiopulmonary resuscitation (CPR) is the foundational technique for the emergency treatment of cardiac arrest, is emphasized more than ever. ${ }^{1}$ The components of CPR are chest compressions and artificial breathing. ${ }^{2}$ Nurses should practice accurately because timely performed CPR can prevent sudden death and increases victim's survival. ${ }^{1,3,4}$

Adequate CPR application requires big efforts, interests, human and economic resources. ${ }^{5}$ After cardiopulmonary arrest, survival is usually low and depends on early intervention, quality of CPR and time to defibrillation. ${ }^{6,7}$ Cardiac arrest brings several complications if it is not done on time. ${ }^{8}$ Nurses are often closest to the bedside and the first to respond to patient's needs. ${ }^{9}$ Identifying knowledge deficits can help in effective planning, implementing the inservice education and hands-on training. ${ }^{10}$

The objectives of this study was to assess knowledge on update for CPR and to identify their relationship with selected variables among the nurses. First CPR guidelines were published in 1966, revised periodically and the recent now in 2015 (American Heart Association AAHA \} guidelines for CPR and Emergency Cardiac Care $\{E C C\}) .{ }^{11}$ Several studies conducted in Nepal have assessed knowledge on CPR and have highlighted the need for training for medical professionals. ${ }^{10,12-14}$ However, there has been no study that assessed knowledge on 2015 AHA guidelines updates for CPR. Such assessment is essential to better understand the current status of nurses' knowledge. It can also inform about the need for the interventions to enhance existing knowledge because it is a major determinant in the success of resuscitation in acute emergency situations. ${ }^{15}$

\section{METHODS}

This cross sectional descriptive study was undertaken at Dhulikhel Hospital, Kathmandu University Hospital (KUH) from May 15 - June 30, 2018. Approval from Institutional Review Committee (IRC), Kathmandu University School of Medical Sciences (KUSMS) was obtained to conduct the study.

A total of 260 nurses working in different departments of Dhulikhel hospital and Kathmandu University School of Medical Sciences (KUSMS) were the participants for the study. Nurses who were on the leave for more than a month were excluded from the study. CPR knowledge was assessed by means of a 20-item self-administered multiple choice questionnaire with four possible responses, with only one correct possibility. The instrument consisted of two parts; first part consisted of sociodemographic characteristics and professional details of the participants and second part consisted theoretical and practical knowledge of the participants on 2015 AHA Guidelines update on CPR that covers the following areas: basics of basic life support, trouble shooting in BLS and advanced cardiac life support.
The content validity of the instrument was enhanced by following the 2015 Guidelines of the AHA for CPR and ECC. Two anaesthesiologists from Dhulikhel hospital evaluated the instrument and validated in its reading comprehension by an initial sample of 10 participants.

All the study participants were informed about the purpose of the study; verbal consent was obtained from each participant before data collection. Appointment for the meeting was taken in each department at the suitable time of the nurses. The questionnaire was distributed and filled out individually by the participants and was collected back at the end of the meeting. Enough time was given to the nurses to fill the questionnaire. The knowledge score was calculated from the total score $(<8=$ poor, $8-10=$ average and $>10=$ good knowledge).

Data was sorted, coded, and entered into Microsoft access and then to Statistical Package for the Social Sciences (SPSS) software version 18 for management and analysis. Descriptive statistics including frequency, mean, range, and standard deviation were used to summarize baseline socio-demographic data. Chi squared test was used for non-parametric categorical data and t-test, Anova (post Hoc test) for parametric data. $P$ value less than 0.05 was considered significant.

\section{RESULTS}

During the study period, a total number of 260 nurses were included in the study. All the participants were female and mean age was $22.4 \pm 4$ years. Knowledge score regarding 2015 AHA Guidelines update for CPR revealed that out of 260 nurses, the minimum correct response was 3 and maximum was 19 . Only one third of the nurses (36\%) had good knowledge, $28 \%$ had average knowledge whereas $36 \%$ had poor knowledge regarding guidelines update for CPR (fig. 1).

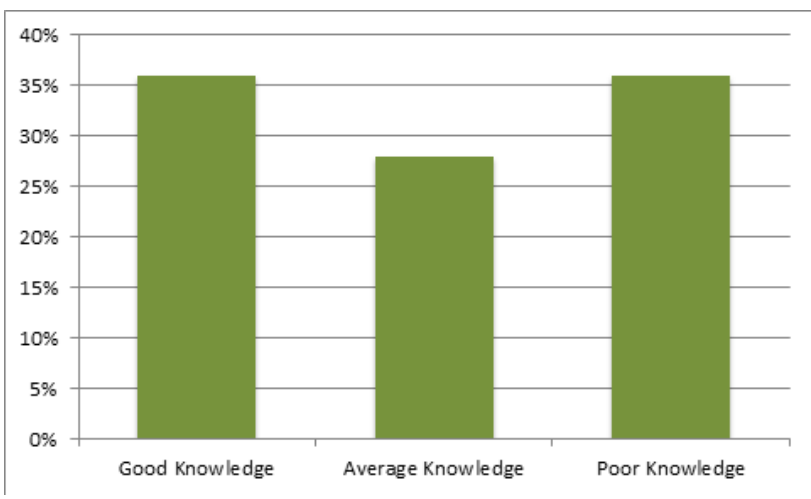

Figure 1. Distribution of respondants' level of knowledge regarding 2015 guidelines update for cardiopulmonary resuscitation.

The highest number of nurses $(48,18.5 \%)$ were working in operation theatre and similarly 208 (80\%) nurses were working in a staff nurse post, majority of nurses $(80 \%)$ had certificate level of nursing education and 101 (39\%) nurses 
had 1-3 years of work experience. Among these nurses, $72 \%$ of nurses had never attended CPR training (Table 1 ).

Table 1. Socio-demographic characteristics and professional details of the respondants

\begin{tabular}{|c|c|c|c|}
\hline Characteristics & Group & Number & Percentage \\
\hline \multirow{6}{*}{ Age } & $16-20$ & 38 & 14.6 \\
\hline & $21-25$ & 154 & 59.2 \\
\hline & $26-30$ & 44 & 16.9 \\
\hline & $31-35$ & 16 & 6.2 \\
\hline & $36-40$ & 3 & 1.2 \\
\hline & $>40$ & 5 & 1.9 \\
\hline \multirow{9}{*}{ Working area } & Nursing Academics & 21 & 8.1 \\
\hline & Intensive Care Unit (ICU) & 35 & 13.5 \\
\hline & Medical Unit & 32 & 12.3 \\
\hline & Emergency Department & 10 & 3.8 \\
\hline & Obstetrics/Gynecology & 35 & 13.5 \\
\hline & Outpatient Department & 12 & 4.6 \\
\hline & Operation Theatre & 48 & 18.5 \\
\hline & Pediatric Department & 30 & 11.5 \\
\hline & Surgical Department & 37 & 14.2 \\
\hline \multirow{4}{*}{ Designation } & Staff Nurse (PCL Nursing) & 208 & 80.0 \\
\hline & $\begin{array}{l}\text { Nursing Incharge (Bach- } \\
\text { elor in nursing, BN) }\end{array}$ & 10 & 3.8 \\
\hline & $\begin{array}{l}\text { Nursing Officer (Bachelor } \\
\text { of Science in nursing, B.Sc. } \\
\text { nursing) }\end{array}$ & 21 & 8.1 \\
\hline & $\begin{array}{l}\text { Nursing Faculty (Masters } \\
\text { in nursing) }\end{array}$ & 21 & 8.1 \\
\hline \multirow{3}{*}{$\begin{array}{l}\text { Highest Aca- } \\
\text { demic Degree }\end{array}$} & Certificate level of nursing & 208 & 80 \\
\hline & Bachelor level of nursing & 31 & 11.9 \\
\hline & Masters level of nursing & 21 & 8.1 \\
\hline \multirow{5}{*}{$\begin{array}{l}\text { Year of profes- } \\
\text { sional experi- } \\
\text { ence }\end{array}$} & $<1$ year & 80 & 30.8 \\
\hline & $1-3$ years & 101 & 38.8 \\
\hline & 3-5 Years & 36 & 13.8 \\
\hline & $5-7$ years & 18 & 6.9 \\
\hline & $>7$ years & 25 & 9.6 \\
\hline \multirow{2}{*}{$\begin{array}{l}\text { Ever attended } \\
\text { CPR Training }\end{array}$} & No & 187 & 71.9 \\
\hline & Yes & 73 & 28.1 \\
\hline
\end{tabular}

In terms of actual real life experience with performing CPR the majority of respondents reported that they had not been required to perform CPR and only $21.9 \%(n=57)$ indicated they had.

The group comparison of the respondents' total scores revealed that there was no significant difference between the knowledge score of the respondents and age of the nurses $(p=0.160)$ and duration of work experience $(p=0.494)$. However, there was a statistically significant association between the knowledge score and qualification, designation of the nurses, attended CPR training or not, involvement in CPR (Table 2). In terms of designation significance was noted (in post hoc test) between staff
Table 2. Relationship of characteristics of the respondents with knowledge regarding $\mathbf{2 0 1 5}$ guidelines update for cardiopulmonary resuscitation.

\begin{tabular}{|llll|}
\hline Characteristics & Group & $\begin{array}{l}\text { Mean } \\
\text { score }\end{array}$ & P value \\
\hline Designation & Staff Nurse & 8.3 & $<0.05$ \\
\hline & Nursing Incharge & 9.7 & \\
& Nursing Officer & 13.1 & \\
\hline & Nursing Faculty & 10.0 & \\
\hline Highest Academic & Certificate level of nursing & 8.2 & \\
Degree & & & \\
\hline$<0.05$ & & & \\
\hline & Masters level of nursing & 9.5 & \\
\hline Ever attended CPR & No & 11.5 & \\
\hline Training & & 8.2 & $<0.05$ \\
\hline & Yachelor level of nursing & 10.4 & \\
\hline Involvement in CPR & Never involved & 8.1 & $<0.05$ \\
\hline & Hardly involved & 9.0 & \\
\hline & Actively involved & 9.9 & \\
\hline
\end{tabular}

nurse, nursing incharge, nursing faculty with nursing officer. Similarly, in terms of qualification of the nurses, significance was noted between the total score of bachelor level of nursing with certificate level of nursing. The nurses working in emergency department had the highest mean score i.e. $12.3 \pm 2.66$, followed by the nurses from intensive care unit (ICU) i.e. $11.9 \pm 3.5$.

Knowledge questions were grouped into three categories that revealed higher percentage of the respondents $(46.18 \%)$ got correct response to the questions regarding basics of basic life support (BLS). Similarly $44.14 \%$ in trouble shooting in BLS and $41.23 \%$ had correct response to the questions regarding advanced cardiac life support (ACLS).

\section{DISCUSSION}

In the present study, nurses' knowledge on 2015 American Heart Association Guidelines update for CPR was observed to be lacking. The percentage of nurses who had good knowledge was only $36 \%$. While CPR/ACLS competency is considered a fundamental skill for health care workers, numerus evidences suggested that knowledge is generally poor, while a study carried out in Spain found a higher level of CPR knowledge among hospital nursing staff. ${ }^{10,13,16,18-21}$ The findings of this study may be explained in part by ineffective initial training and/or refresher training thus emphasizes the importance of increasing the CPR knowledge and skills of the nurses. Competent and knowledgeable nurses can implement effective CPR interventions to save patients' lives. ${ }^{22}$ Nurses spend significant time alongside patients and are often the first to attend at in hospital cardiovascular arrests; they are thus the ones who respond by providing CPR. The ability to 
respond quickly and effectively to a cardiac arrest situation rests on nurses being knowledgeable and competent in CPR. ${ }^{21}$ Studies have shown that training programs in CPR may augment nurses' theoretical knowledge and may make a significant contribution to the elimination of their anxiety and an increase in their self confidence and effectiveness in dealing with a cardiac arrest, individually or as members of a team..$^{23}$ The result of the current study showed that the majority of nurses didn't have previous training related to CPR. This result is in accordance with the study Damjan $L$ that stated that more than two third of the participants didn't have any previous training regarding CPR. ${ }^{24}$

The group comparison of the respondents' total scores revealed that there was no significant difference between the knowledge score of the respondents and age of the nurses in the present study. Similar findings were revealed in many other studies, whereas in other studies, the result was significant. $10,14,18,20,22,25,26$ Non-significance between duration of work experience and the knowledge of nurses $(p=0.494)$ in this study has been also reported by several other studies. ${ }^{10,13,16,17,20,22}$ However, in other studies, it was found that there was an improvement in the level of nurses' knowledge with the increase in the years of work experience. ${ }^{25,27}$

There was a statistically significant association between the knowledge scores and qualification of the nurses in this study and this findings was also evidenced by many other studies. . $^{10,17,18,22,25}$

The highest level of knowledge was observed in the participants who had attended CPR training. This finding was in agreement with the results of other studies. ${ }^{17,22,25,27}$ Similarly in a study done by Moura et al. they found that the participants who had attended a training course had a better performance on questionnaire i.e. $62.5 \%$ versus

\section{REFERENCES}

1. LS Nisha. A study to assess the knowledge about cardio pulmonary resuscitation guidelines among cardiac nurses. Project report. November 2011. Available at http://dspace.sctimst.ac.in/jspui/ bitstream/123456789/1599/1/473.pdf.

2. Hazinski MF. American Heart Association Guidelines for CPR and ECC. American Heart Association 2010. Available at https://www. heart.org/idc/groups/heart-public/@wcm/@ecc/documents/ downloadable/ucm_317350.pdf.

3. Madden $\mathrm{C}$. Undergraduate nursing students acquisition and retention of CPR knowledge and skills. Nurse Education Today. 2006;26:218-27. Doi: 10.1016/j.nedt.2005.10.003.

4. American Guidelines for Cardiopulmonary Resuscitation and Emergency Cardiovascular Care. Circulation. 2005; 13 (14): 1-203. Available from https://www.ncbi.nlm.nih.gov/pubmed/16314375

5. American Heart Association and National Academy of SciencesNational Research Council. Standards and guidelines for cardiopulmonary resuscitation and emergency cardiac care. JAMA. 1986;255(21):2905-84. Available from https://www.ncbi.nlm.nih. gov/pubmed/2871200. only $22.61 \%$ of the participants who had not attended any CPR training course $(p=0.007) .{ }^{28}$ Similarly, in terms of qualification of the nurses, significance was noted between the total score of bachelor level of nursing with certificate level of nursing. Evidence suggested that there is a significant relationship between knowledge on CPR and qualification of nurses, however a few studies found there is no difference. ${ }^{10,13,14,20,22,25,26}$

It is found that the nurses working in emergency department had the highest mean score i.e. $12.3 \pm 2.66$, followed by the nurses from ICU i.e. $11.9 \pm 3.5$ in this study whereas in a study done by Parajuli et al. nurses from hemodialysis had highest score followed by the nurses from obstetrics and gynaecology. ${ }^{10}$

\section{CONCLUSION}

The study revealed that only one third of the nurses have good knowledge regarding 2015 American Heart Association Guidelines update for Cardiopulmonary Resuscitation. Thus, their knowledge and practical approach has to be updated with current guidelines of AHA in CPR in order to improve the safety and effectiveness of patient care. Health care managers and policy makers should take this finding into consideration. CPR educational program should be included in all nursing schools and curricula. Structured CPR training program should be conducted regularly to train and educate all nurses.

\section{ACKNOWLEDGMENTS}

We would like to express our gratitude to all the nurses and anesthesiologists at Dhulikhel Hospital, Kathmandu University Hospital.

6. Ritter G, Wolfe RA, Goldstein S, Landis JR, Vasu CM, Acheson A, et al. The effect of by-stander CPR on survival of out-of-hospital cardiac arrest victims. Am Heart J. 1985; 110: 932-937.Available from https:// www.ncbi.nlm.nih.gov/pubmed/4061266.

7. Wik L, Steen PA, Bircher NG. Quality of bystander cardiopulmonary resuscitation influences outcome after prehospital cardiac arrest. Resuscitation. 1994; 28: 195-203. Available from https://www.ncbi. nlm.nih.gov/pubmed/7740189.

8. Beauchamp M, Tom O, Walters S, Khan I, Anna, F. Trends in cardiopulmonary resuscitation: a four year review. West Afr. J. Med. 2008(19), 25- 30. Available from https://www.sciencedirect.com/ science/article/pii/S2211419X16301872.

9. Bull S, Alex B. Cardiopulmonary Resuscitation Media Guideline. 2007. Retrieved September 2018. Available from http://cache44.clip.dj/srv/ get.php?f=mp3\&id=ZjszBXF0|8A\&title=Cardiopulmonary+Resuscitati on+(CPR)+Guidelines+\%27ABCDS\%27+is+now+\%27AB-CABS\%27\&q=

10. Parajuli S, SelVaraj V. Knowledge of Nurses towards Cardio-pulmonary Resuscitation in a Tertiary Care Teaching Hospital in Nepal. Journal of Clinical and Diagnostic Research. 2011; 5(8): 1585-1588. Available from http://www.jcdr.net/articles/PDF/1720/22\%20-\%203113.pdf. 
11. Cardiopulmonary resuscitation. JAMA. 1966; 198:372-379. doi:10.1001/jama.1966.03110170084023.

12. Shrestha R, Batajoo KH, Piryani RM, Sharma MW. Basic life support: knowledge and attitude of medical/paramedical professionals. World J Emerg Med. 2012;3(2):141-145. DOI: 10.5847/ wjem.j.is sn.1920-8642.2012.02.011.

13. Bajracharya S, Nagarkoti L. Knowledge Regarding Basic Life Support Among Nurses of a Tertiary Level Hospital of Nepal. MJSBH. 2016;15(1):66-69.

14. Amatya M, Gorkhali B. Cardiopulmonary resuscitation: knowledge amongst Nepalese health personnel. Janaki Medical College Journal of Medical Sciences. 2015;3(1):25-30.

15. Reddy S, Doshi D, Reddy P, Kulkarni S, Reddy S. Awareness of basic life support among staff and students in a dental school. The journal of contemporary dental practice. 2013 May 1;14(3):511-7.

16. García S, Belén A, Alemán F, Pérez JLA, Valverde N, Castro R. Assessment of the knowledge level and its relevance in terms of CPR in medical personnel of the hospital emergency medical system of the Autonomous Community of the region of Murcia. Enfermeria Global. 2015; 39:246-60. Available from http://scielo.isciii.es/pdf/eg/ v14n39/en_administracion3.pdf.

17. Batool AJA. Assessment of Nurses' Knowledge towards Cardiopulmonary Resuscitation at Al-Najaf City's Teaching Hospital. Journal of Kufa for Nursing Science. 2014; 4(1): 1-10. Available from https://www.iasj.net/iasj?func=fulltext\&ald=88992.

18. Marzooq H, Lyneham J. Cardio-pulmonary resuscitation knowledge among nurses who work in Bahrain. International Journal of Nursing Practice. 2009; 15(4): 294-302. DOI:10.1111/j.1440172X.2009.01752.x

19. Bukiran A, Erdur B, Ozen M, Bozhurt Al, Denizli A. Retention of Nurses' Knowledge after BLS/ACLS training at immediate, 6-month, and 12-month post-training intervals: a longitudinal study of nurses in turkey. J Emerg Nurs. 2012. Retrieved September 2018. Available from http://dx.doi.org/10.1016/j.jen.2012.08.011.

20. Rajeswaran L, Ehlers VJ. Cardio-Pulmonary Resuscitation knowledge and skills of Registered Nurses in Botswana. Journal of the democratic Nursing organization of South Africa. 2014;37(1). DOI:10.4102/ curationis.v37i1.1259.
21. Garcia JC, Torrent AA, Racoba-Zoff G, Monsequr JC.Perception of the health professionals of the Hospital SantLlorenç de Viladecans about their knowledge and skills in cardiopulmonary resuscitation. Clinical Nursing. 2006; 1(1): 39-43.DOI:10.1016/S1130-8621(06)71176-7.

22. El- Meanawi NH. Assessment of Nurses Performance during Cardiopulmonary Resuscitation in Intensive Care Unit and Cardiac Care Unit at the Alexandria Main University Hospital. International journal of scientific \& technology research. 2015; 4(2). Available from https://www.ijstr.org/final-print/dec2015/Assessment-Of-NursesPerformance-During-Cardiopulmonary-Resuscitation-In-IntensiveCare-Unit-And-Cardiac-Care-Unit-At-The-Alexandria-Main-UniversityHospital.pdf.

23. Källestedt ML, Berglund A, Herlitz J, Leppert J, Enlund M. The impact of CPR and AED training on healthcare professionals' self-perceived attitudes to performing resuscitation. Scand I Trauma Resusc Emerg Med. 2012; 20-6. Doi: 10.1186/1757-7241-20-26.

24. Damjan L, Bojan L, Jerneja, G. Impact of additional module training on the level of basic life support knowledge of first year student at the University of Maribor. International Journal of Emergency Medicine. 2012: 4, 16. Available from https://doi.org/10.1186/1865-1380-4-16.

25. Mohamed Al, Elbana HM, Elhaleim SA. Maternity Nurses' Performance Regarding Cardiopulmonary Resuscitation during Pregnancy: Simulation Based Intervention. International Journal of Studies in Nursing. 2018; 3(1): 144-57. Available from https://doi. org/10.20849/ijsn.v3i1.356.

26. Aly A. Impact of a basic life support training program on nurses' knowledge and performance at emergency room. Doctorate thesis, Faculty of nursing, Suez Canal University. 2010.

27. Al-Kandary C, Al-Jeheidli A, Ghayath T, Al-Haid N. Perceived Competence in Cardiopulmonary Resuscitation, Knowledge and Practice among Qualified Nurses In Kuwait. Alexandria Bullettin Bill. Alex. Fac. 2007; 43(2).

28. Moura FS, Carvalho FV, Martins MC, Vasconcelos GM, Mello PM. Knowledge of Guidelines for Cardiopulmonary Resuscitation among Brazilian Medical Students. Revista Brasileira de educação Médica. 2016; 77(1): 77-85. Available fromhttp://dx.doi.org/10.1590/1981$52712015 v 40 n 1 \mathrm{e} 01772015$. 


\section{Towards Vision 2020 -Trends of Cataract Surgery in Melaka Hospital, A Malaysian Tertiary Center: 2007-2014 Thevi T, ${ }^{1}$ Abas $A^{2}$}

\author{
Corresponding Author \\ Thanigasalam Thevi \\ Department of Ophthalmology \\ Hospital Melaka, \\ Jalan Mufti Haji Khalii, \\ 75400 Melaka, Malaysia. \\ E-mail: 111thevi@gmail.com
}

Citation

Thevi T, Abas AL. Towards Vision 2020-Trends of Cataract Surgery in Melaka Hospital, A Malaysian Tertiary Center: 2007-2014. Kathmandu Univ Med J. Online First.

\begin{abstract}
Background

Cataract surgery which is the only scientific method to treat cataracts has evolved from large incisions of intracapsular cataract excision to extracapsular cataract exicison and now modern day phacoemulsification. Anaesthesia too has progressed from general anaesthesia to local and topical anaesthesia. A variety of intraocular lenses are available ranging from rigid to foldable, multifocal and toric. Day care surgeries are becoming the norm these days.
\end{abstract}

\section{Objective}

Cataract surgery has advanced with new techniques and modalities. We studied the trends of cataract surgery and outcomes over the years.

\section{Method}

We performed secondary data analysis (National Eye Database) of cataract surgery patients in Hospital Melaka (2007 - 2014).

Result

Most patients were 60-69 years (mean 65.0 years). Primary cataract rose $(p<0.05)$ but there was no difference in laterality and first or second eye $(p>0.05)$. More patients presented with Hypertension and Diabetes $(p<0.05)$. Pterygium encroaching the cornea showed a rise $(p<0.05)$. Phacoemulsification $(80.8 \%)$ showed a rise while Extracapsular Cataract Extraction (ECCE) (15.4\%) declined $(p<0.05)$. More Specialists operated and fewer combined surgeries were performed $(p<0.001)$. Type of anaesthesia did not change ( $p>0.05)$. Operative complications reduced $(p<0.001)$. Anterior chamber, scleral fixated and foldable intraocular lenses usage reduced $(p<0.05)$. There was no change in pre-operative visual acuity $(p>0.05)$ but postoperative vision showed a rise in good outcomes $(p<0.05)$.

\section{Conclusion}

Melaka Hospital shows a rise in phacoemulsification and a decline in Extracapsular Cataract Extraction. More patients presented with primary cataracts. More Specialists operated and there was a reduction in intraoperative and postoperative complications. Post-operative visual outcomes showed a remarkable improvement. This improvement is in keeping with the aim of improved vision for all by 2020 .

\section{KEY WORDS}

Cataract surgery, Trends, Malaysian tertiary center 


\section{INTRODUCTION}

Vision 2020: the right to sight is a global initiative with joint partnership between the World Health Organization (WHO) and several Non-Governmental Organizations (NGOs) which was launched in 1999 with the main aim of eliminating blindness by the year $2020 .{ }^{1}$ Cataract is the leading cause of blindness in the world accounting for $51 \%$ (20 million) of the cases in $2010 .^{2}$ In Malaysia, cataract is the principal cause of blindness (39\%) according to a survey conducted in 1999. ${ }^{3}$ The ultimate aim of cataract surgery is to restore vision and alleviate all symptoms associated with it which include glare and halos. Cataract surgery has changed over the years with improved techniques, equipment and anaesthesia. Initially Intracapsular cataract extraction was done removing the entire lens with the capsule. This later was taken over by extracapsular cataract extraction (ECCE) and today phacoemulsification is being utilized regularly as the operation of choice for cataract surgery. The incision size too has decreased tremendously from $12 \mathrm{~mm}$ to 1.2 $\mathrm{mm}$. Surgery is now sutureless in phacoemulsification and it is faster. The use of General Anaesthesia is restricted to those with mental health problems, children and others who are not cooperative for surgery. Most cases are now done under topical anaesthesia. Admissions into the wards are now a thing of the past as patients undergo day care surgery where they go to the day care center for surgery and are discharged a few hours later. The design and material for intraocular lenses and the design of equipment used is more sophisticated.

This has set a trend in the practice pattern of cataract surgery and the final goal is to achieve perfect vision with a good technique which is painless with rapid recovery and early discharge. In tandem with the advancement of Science and Technology, patients have now become internet savvy and these advances are necessary in keeping abreast with the active lifestyles patients lead today.

We did an analysis to see the practice patterns and trends of cataract surgery in our hospital which is a tertiary hospital in Malaysia and serves as a teaching hospital for Melaka Manipal Medical students.

\section{METHODS}

Vision 2020: the right to sight is a global initiative with joint partnership between the World Health Organization (WHO) and several Non-Governmental Organizations (NGOs) which was launched in 1999 with the main aim of eliminating blindness by the year $2020 .{ }^{1}$ Cataract is the leading cause of blindness in the world accounting for $51 \%$ (20 million) of the cases in $2010 .^{2}$ In Malaysia, cataract is the principal cause of blindness (39\%) according to a survey conducted in 1999. ${ }^{3}$ The ultimate aim of cataract surgery is to restore vision and alleviate all symptoms associated with it which include glare and halos. Cataract surgery has changed over the years with improved techniques, equipment and anaesthesia. Initially Intracapsular cataract extraction was done removing the entire lens with the capsule. This later was taken over by extracapsular cataract extraction (ECCE) and today phacoemulsification is being utilized regularly as the operation of choice for cataract surgery. The incision size too has decreased tremendously from $12 \mathrm{~mm}$ to 1.2 $\mathrm{mm}$. Surgery is now sutureless in phacoemulsification and it is faster. The use of General Anaesthesia is restricted to those with mental health problems, children and others who are not cooperative for surgery. Most cases are now done under topical anaesthesia. Admissions into the wards are now a thing of the past as patients undergo day care surgery where they go to the day care center for surgery and are discharged a few hours later. The design and material for intraocular lenses and the design of equipment used is more sophisticated.

This has set a trend in the practice pattern of cataract surgery and the final goal is to achieve perfect vision with a good technique which is painless with rapid recovery and early discharge. In tandem with the advancement of Science and Technology, patients have now become internet savvy and these advances are necessary in keeping abreast with the active lifestyles patients lead today.

We did an analysis to see the practice patterns and trends of cataract surgery in our hospital which is a tertiary hospital in Malaysia and serves as a teaching hospital for Melaka Manipal Medical students.

\section{RESULTS}

\section{Hospital Melaka Cataract Database}

There were altogether a total of 12,992 patients who were admitted for cataract surgeries in Hospital Melaka between 2007 and 2014.

The mean age of these patients was 65.0 years of age (Table 1). Most were between 60 to 69 years of age (38.7\% of total patients), 70 to 79 years of age (31.5\% of total patients), 50 to 59 years of age ( $17.8 \%$ of total patients) and more than 80 years of age ( $5.3 \%$ of total patients). The rest of the age groups comprised of the 0 to 9 years of age which provides $0.5 \%$ of total patients for cataract surgery with the 20 to 29 years of age and 10 to 19 years of age providing $0.6 \%$ and $0.3 \%$ of total patients respectively.

The patients comprised of $53.0 \%$ females and $47.0 \%$ males (Table 1). The main ethnic group that were operated upon comprised of the Malays (47.8\%) followed by Chinese (38.2\%) and the Indians (12.4\%).

As for types of cataract operation, Phacoemulsification cataract surgery was the commonest type with $80.8 \%$ of total cataract operations followed by ECCE at $15.4 \%$, conversion of Phacoemulsification to ECCE at $1.4 \%$ and lens aspiration at $1.2 \%$ (Table 2 ). 
Table 1. Descriptive statistics of basic variables among patients undergoing cataract operation, Hospital Melaka, 2007 to 2014

\begin{tabular}{|lll|}
\hline \multirow{2}{*}{ Age (Mean + Standard Deviation) } & Values \\
\hline & 0 to 9 years & $65.0+11.2$ \\
\hline 10 to 19 years & $67(0.5)$ \\
\hline 20 to 29 years & $34(0.3)$ \\
\hline \multirow{5}{*}{ Age groups } & $74(0.6)$ \\
\hline & 40 to 39 years & $132(1.0)$ \\
\hline 40 to 49 years & $558(4.3)$ \\
\hline 50 to 59 years & $2316(17.8)$ \\
\hline 60 to 69 years & $5029(38.7)$ \\
\hline Gender & 70 to 79 years & $4090(31.5)$ \\
\hline more than 80 years & $688(5.3)$ \\
\hline Female & $6881(53.0)$ \\
\hline Male & $6110(47.0)$ \\
\hline Chinese & $4963(38.2)$ \\
\hline Iban & $2(0.0)$ \\
\hline Ethnicity & Indian & $1608(12.4)$ \\
\hline Kadazan / Murut / Bajau & $3(0.0)$ \\
\hline Malay & $6209(47.8)$ \\
\hline Other & $88(0.7)$ \\
\hline Total & $12992(100)$ \\
\hline
\end{tabular}

Table 2. Types of cataract operation, Hospital Melaka, 2007 to 2014

\begin{tabular}{|l|l|}
\hline Variables & $\begin{array}{l}\text { Values } \\
\text { No (\%) }\end{array}$ \\
\hline Types of cataract operation & \\
\hline ECCE & $2000(15.4)$ \\
\hline ICCE & $78(0.6)$ \\
\hline Lens aspiration & $161(1.2)$ \\
\hline Phaco & $10497(80.8)$ \\
\hline Phaco converted to ECCE & $185(1.4)$ \\
\hline Other & $45(0.3)$ \\
\hline Not available & $26(0.2)$ \\
\hline Total & $12992(100)$ \\
\hline
\end{tabular}

Table 3. Types of cataract operation complications, Hospital Melaka, 2007 to 2014

\begin{tabular}{|ll|}
\hline Variables & $\begin{array}{l}\text { Values } \\
\text { No (\%) }\end{array}$ \\
\hline Types of cataract operation complications & \\
\hline Posterior capsule rupture & $623(4.8)$ \\
\hline Vitreous loss & $411(3.2)$ \\
\hline Zonular dehiscence & $146(1.1)$ \\
\hline Dropped nucleus & $17(0.1)$ \\
\hline Other intra-operative complications & $145(1.1)$ \\
\hline No intra-operative complication & $12045(92.7)$ \\
\hline Total & $12992(100)$ \\
\hline
\end{tabular}

As shown in Table 3, 7.3\% of the total cataract operations presented with complications. Posterior capsule rupture contributed to the highest percentage of total complications with $4.8 \%$ followed by vitreous loss at $3.2 \%$, zonular dehiscence at $1.1 \%$ and dropped nucleus at $0.1 \%$.

Table 4 provides the number and percentage of reported cataract operations by year, laterality, cause of cataract, presence and absence of systemic diseases for these 12,992 individuals. The percentage of cataract as a result of primary causes rose from $96.7 \%$ of total cataract operations in 2007 to $97.3 \%$ in 2014 ( $p$ value <0.05).

The percentage of presence of hypertension among individuals undergoing cataract operation increased from $52.5 \%$ of total cataract operations in 2007 to $61.9 \%$ in 2014 ( $p$ value $<0.05$ ). We also observed an increase in percentage of presence of diabetes mellitus among individuals undergoing cataract operation from $43.5 \%$ of total cataract operations in 2007 to $50.6 \%$ in 2014 (p value < 0.05; Table 4. However, there were no significant differences in trends for the other systemic diseases monitored such as ischaemic heart disease, renal failure and cerebrovascular diseases ( $p$ value $>0.05$ ).

With regards to laterality, there was no significant difference in the trend of percentage of total cataract operations with left eye cataract operations contributing $49.1 \%$ of total cataract operations in 2014 ( $p$ value >0.05; Table 4). There was also no significant difference in the trend of percentage of total cataract operations with regards to whether first or second eye was operated upon ( $p$ value $>0.05$ ).

Table 5 illustrates the number and percentage of reported cataract operations by year and ocular morbidity. The percentage of pterygia encroaching onto cornea rose from $0.9 \%$ of total cataract operations in 2007 to $2.0 \%$ in 2014 (p value $<0.05$ ).

There was significant reduction in the trend of percentage of reported cataract operations ( $p$ value $<0.05$; Table 5) among patients with coexisting glaucoma-both open and closed angles glaucoma ( $7.8 \%$ of total cataract operations in 2007 to $3.8 \%$ of total cataract operations in 2014); as well as phacomorphic glaucoma $(0.4 \%$ of total cataract operations in 2007 to $0.0 \%$ of total cataract operations in 2014). There was also a reduction in coexisting ocular comorbidities of proliferative diabetic retinopathy (PDR) (8.2\% of total cataract operations in 2007 to $3.5 \%$ of total cataract operations in 2014) and vitreous hemorrhage (VH) (1.3\% of total cataract operations in 2007 to $0.4 \%$ of total cataract operations in 2014).

However, there were no significant differences in trends of percentage of total cataract operations ( $p$ value > 0.05; Table 5) with regards to presence of other ocular comorbidities such as corneal opacity $10.5 \%$ of total cataract operations in 2014), chronic uveitis (0.3\% of total cataract operations in 2014), pseudoexfoliation (1.1\% of 
Table 4. Number and percentage of reported cataract operations by year, laterality, cause of cataract and systemic diseases, Hospital Melaka, 2007-2014

\begin{tabular}{|c|c|c|c|c|c|}
\hline & $\begin{array}{l}2007 \\
\text { N (\%) }\end{array}$ & $\begin{array}{l}2014 \\
\text { N (\%) }\end{array}$ & $\begin{array}{l}\text { Total } \\
2007- \\
2014 \mathrm{~N} \\
(\%)\end{array}$ & $\begin{array}{l}\text { Chi } \\
\text { Square } \\
\text { for Trend }\end{array}$ & $P$ value \\
\hline Total & $\begin{array}{l}1527 \\
(100)\end{array}$ & $\begin{array}{l}1872 \\
(100)\end{array}$ & $\begin{array}{l}12992 \\
(100)\end{array}$ & & \\
\hline \multicolumn{6}{|l|}{ Laterality } \\
\hline Left eye & $\begin{array}{l}776 \\
(50.8)\end{array}$ & $\begin{array}{l}919 \\
(49.1)\end{array}$ & $\begin{array}{l}6387 \\
(100)\end{array}$ & 0.002 & 0.965 \\
\hline Right eye & $\begin{array}{l}751 \\
(49.2)\end{array}$ & $\begin{array}{l}953 \\
(50.9)\end{array}$ & $\begin{array}{l}6604 \\
(100)\end{array}$ & & \\
\hline \multicolumn{6}{|l|}{ Operated upon } \\
\hline First eye & $\begin{array}{l}1005 \\
(65.8)\end{array}$ & $\begin{array}{l}1183 \\
(63.2)\end{array}$ & $\begin{array}{l}8292 \\
(100)\end{array}$ & 0.008 & 0.929 \\
\hline Second eye & $\begin{array}{l}522 \\
(34.2)\end{array}$ & $\begin{array}{l}679 \\
(36.3)\end{array}$ & $\begin{array}{l}4677 \\
(100)\end{array}$ & & \\
\hline \multicolumn{6}{|l|}{ Cause of } \\
\hline Primary & $\begin{array}{l}1477 \\
(96.7)\end{array}$ & $\begin{array}{l}1821 \\
(97.3)\end{array}$ & $\begin{array}{l}12680 \\
(100)\end{array}$ & 41.904 & $\mathrm{P}<0.001 * * *$ \\
\hline Secondary & $\begin{array}{l}47 \\
(3.1)\end{array}$ & $\begin{array}{l}14 \\
(0.7)\end{array}$ & $147(100)$ & & \\
\hline \multicolumn{6}{|c|}{ Systemic diseases } \\
\hline Hypertension & $\begin{array}{l}802 \\
(52.5)\end{array}$ & $\begin{array}{l}1158 \\
(61.9)\end{array}$ & $\begin{array}{l}7587 \\
(100)\end{array}$ & 38.073 & $\mathrm{P}<0.001 * * *$ \\
\hline No & $\begin{array}{l}725 \\
(47.5)\end{array}$ & $\begin{array}{l}714 \\
(38.1)\end{array}$ & $\begin{array}{l}5405 \\
(100)\end{array}$ & & \\
\hline $\begin{array}{l}\text { Diabetes } \\
\text { Mellitus }\end{array}$ & $\begin{array}{l}665 \\
(43.5)\end{array}$ & $\begin{array}{l}947 \\
(50.6)\end{array}$ & $\begin{array}{l}5839 \\
(100)\end{array}$ & 39.946 & $\mathrm{P}<0.001 * * *$ \\
\hline No & $\begin{array}{l}862 \\
(56.5)\end{array}$ & $\begin{array}{l}925 \\
(49.4)\end{array}$ & $\begin{array}{l}7153 \\
(100)\end{array}$ & & \\
\hline $\begin{array}{l}\text { Ischaemic } \\
\text { heart disease }\end{array}$ & $\begin{array}{l}172 \\
(11.3)\end{array}$ & $\begin{array}{l}178 \\
(9.5)\end{array}$ & $\begin{array}{l}1361 \\
(100)\end{array}$ & 3.596 & 0.057 \\
\hline No & $\begin{array}{l}1355 \\
(88.7)\end{array}$ & $\begin{array}{l}1694 \\
(90.5)\end{array}$ & $\begin{array}{l}11631 \\
(100)\end{array}$ & & \\
\hline Renal failure & $\begin{array}{l}41 \\
(2.7)\end{array}$ & $\begin{array}{l}45 \\
(2.4)\end{array}$ & $312(100)$ & 4.902 & 0.026 \\
\hline No & $\begin{array}{l}1486 \\
(97.3)\end{array}$ & $\begin{array}{l}1827 \\
(97.6)\end{array}$ & $\begin{array}{l}12680 \\
(100)\end{array}$ & & \\
\hline $\begin{array}{l}\text { Cerebro- } \\
\text { vascular } \\
\text { accident }\end{array}$ & $0(0)$ & $\begin{array}{l}17 \\
(0.9)\end{array}$ & $98(100)$ & 6.495 & $0.010 * * *$ \\
\hline No & $\begin{array}{l}1527 \\
(100)\end{array}$ & $\begin{array}{l}1855 \\
(99.1)\end{array}$ & $\begin{array}{l}12894 \\
(100)\end{array}$ & & \\
\hline
\end{tabular}

total cataract operations in 2014) and maculopathy $(2.0 \%$ of total cataract operations in 2014).

Table 6 shows the number and percentages of reported cataract operations by year and pre-operation visual acuity. There were no significant differences in trends of percentage of good vision among right unaided preoperation, left unaided pre-operation, right refracted preoperation and left refracted pre-operation ( $p$ value $>0.05$; Table 6). Good vision were noted at $18.2 \%, 17.5 \%, 26.2 \%$ and $23.6 \%$ of total cataract operations in 2014 respectively
Table 5. Number and percentage of reported cataract operations by year and ocular morbidity, Hospital Melaka, 2007-2014

\begin{tabular}{|c|c|c|c|c|c|}
\hline & $\begin{array}{l}2007 \\
\text { N (\%) }\end{array}$ & $\begin{array}{l}2014 \\
N(\%)\end{array}$ & $\begin{array}{l}\text { Total } \\
2007- \\
2014 \\
\text { N (\%) }\end{array}$ & $\begin{array}{l}\text { Chi } \\
\text { Square } \\
\text { for } \\
\text { Trend }\end{array}$ & $P$ value \\
\hline Total & $\begin{array}{l}1527 \\
(100)\end{array}$ & $\begin{array}{l}1872 \\
(100)\end{array}$ & $\begin{array}{l}12992 \\
(100)\end{array}$ & & \\
\hline \multicolumn{6}{|c|}{ Ocular comorbidity } \\
\hline $\begin{array}{l}\text { Pterygium } \\
\text { into } \\
\text { cornea }\end{array}$ & $14(0.9)$ & $38(2.0)$ & $\begin{array}{l}194 \\
(100)\end{array}$ & 10.688 & $0.001 * * *$ \\
\hline No & $\begin{array}{l}1513 \\
(99.1)\end{array}$ & $\begin{array}{l}1834 \\
(98)\end{array}$ & $\begin{array}{l}12798 \\
(100)\end{array}$ & & \\
\hline $\begin{array}{l}\text { Corneal } \\
\text { opacity }\end{array}$ & $7(0.5)$ & $10(0.5)$ & $94(100)$ & 0.122 & 0.727 \\
\hline No & $\begin{array}{l}1520 \\
(99.5)\end{array}$ & $\begin{array}{l}1862 \\
(99.5)\end{array}$ & $\begin{array}{l}12898 \\
(100)\end{array}$ & & \\
\hline Glaucoma & $119(7.8)$ & $72(3.8)$ & $\begin{array}{l}863 \\
(100)\end{array}$ & 65.294 & $\mathrm{P}<0.001 * * *$ \\
\hline No & $\begin{array}{l}1408 \\
(92.2)\end{array}$ & $\begin{array}{l}1800 \\
(96.2)\end{array}$ & $\begin{array}{l}12129 \\
(100)\end{array}$ & & \\
\hline $\begin{array}{l}\text { Chronic } \\
\text { Uveitis }\end{array}$ & $7(0.5)$ & $6(0.3)$ & $44(100)$ & 0.193 & 0.660 \\
\hline No & $\begin{array}{l}1520 \\
(99.5)\end{array}$ & $\begin{array}{l}1866 \\
(99.7)\end{array}$ & $\begin{array}{l}12948 \\
(100)\end{array}$ & & \\
\hline $\begin{array}{l}\text { Pseudoex- } \\
\text { foliation }\end{array}$ & $17(1.1)$ & $20(1.1)$ & $\begin{array}{l}149 \\
(100)\end{array}$ & 0.472 & 0.492 \\
\hline No & $\begin{array}{l}1510 \\
(98.9)\end{array}$ & $\begin{array}{l}1852 \\
(98.9)\end{array}$ & $\begin{array}{l}12843 \\
(100)\end{array}$ & & \\
\hline $\begin{array}{l}\text { Phaco- } \\
\text { morphic }\end{array}$ & $6(0.4)$ & $0(0)$ & $29(100)$ & 4.543 & $0.003 * * *$ \\
\hline No & $\begin{array}{l}1521 \\
(99.6)\end{array}$ & $\begin{array}{l}1872 \\
(100)\end{array}$ & $\begin{array}{l}12963 \\
(100)\end{array}$ & & \\
\hline $\begin{array}{l}\text { Prolifera- } \\
\text { tive DR }\end{array}$ & $125(8.2)$ & $62(3.3)$ & $\begin{array}{l}581 \\
(100)\end{array}$ & 75.743 & $P<0.001 * * *$ \\
\hline No & $\begin{array}{l}1402 \\
(91.8)\end{array}$ & $\begin{array}{l}1810 \\
(96.7)\end{array}$ & $\begin{array}{l}12411 \\
(100)\end{array}$ & & \\
\hline $\begin{array}{l}\text { Macu- } \\
\text { lopathy }\end{array}$ & $18(1.2)$ & $37(2.0)$ & $\begin{array}{l}175 \\
(100)\end{array}$ & 3.555 & 0.059 \\
\hline No & $\begin{array}{l}1509 \\
(98.8)\end{array}$ & $\begin{array}{l}1835 \\
(98)\end{array}$ & $\begin{array}{l}12817 \\
(100)\end{array}$ & & \\
\hline $\begin{array}{l}\text { Vitreous } \\
\text { haemor- } \\
\text { rhage }\end{array}$ & $20(1.3)$ & $7(0.4)$ & $97(100)$ & 23.706 & $P<0.001 * * *$ \\
\hline No & $\begin{array}{l}1507 \\
(98.7)\end{array}$ & $\begin{array}{l}1865 \\
(99.6)\end{array}$ & $\begin{array}{l}12895 \\
(100)\end{array}$ & & \\
\hline ARMD & $23(1.5)$ & $26(1.4)$ & $\begin{array}{l}207 \\
(100)\end{array}$ & 0.024 & 0.877 \\
\hline No & $\begin{array}{l}1504 \\
(98.5)\end{array}$ & $\begin{array}{l}1846 \\
(98.6)\end{array}$ & 12785 & & \\
\hline$\sim$ Proliferati & e Diabetic & tinopathy & & & \\
\hline
\end{tabular}

for right unaided pre-operation, left unaided preoperation, right refracted pre-operation and left refracted pre-operation. There were no significant changes in trends 
for impaired and poor vision in 2014 respectively for right unaided pre-operation, left unaided pre-operation, right refracted pre-operation and left refracted pre-operation ( $p$ value > 0.05; Table 6).

Table 6. Number and percentage of reported cataract operations by year and pre-operation visual acuity, Hospital Melaka, 2007-2014

\begin{tabular}{|c|c|c|c|c|c|}
\hline & $\begin{array}{l}2007 \mathrm{~N} \\
(\%)\end{array}$ & $\begin{array}{l}2014 \mathrm{~N} \\
(\%)\end{array}$ & $\begin{array}{l}\text { Total } \\
2007- \\
2014 \\
\text { N (\%) }\end{array}$ & $\begin{array}{l}\text { Chi Square } \\
\text { for Trend }\end{array}$ & $\begin{array}{l}\mathbf{P} \\
\text { value }^{\sim}\end{array}$ \\
\hline Total & $\begin{array}{l}1527 \\
(100)\end{array}$ & $\begin{array}{l}1872 \\
(100)\end{array}$ & $\begin{array}{l}12992 \\
(100)\end{array}$ & & \\
\hline \multicolumn{6}{|c|}{ Right unaided Pre-op } \\
\hline Good vision & $\begin{array}{l}300 \\
(19.6)\end{array}$ & $\begin{array}{l}340 \\
(18.2)\end{array}$ & $\begin{array}{l}2469 \\
(100)\end{array}$ & 0.159 & 0.690 \\
\hline $\begin{array}{l}\text { Impaired } \\
\text { vision }\end{array}$ & $\begin{array}{l}606 \\
(39.7)\end{array}$ & $\begin{array}{l}677 \\
(36.2)\end{array}$ & $\begin{array}{l}4771 \\
(100)\end{array}$ & & \\
\hline Poor vision & $\begin{array}{l}618 \\
(40.5)\end{array}$ & $\begin{array}{l}825 \\
(44.1)\end{array}$ & $\begin{array}{l}5483 \\
(100)\end{array}$ & & \\
\hline \multicolumn{6}{|c|}{ Left unaided Pre-op } \\
\hline Good vision & $275(18)$ & $\begin{array}{l}327 \\
(17.5)\end{array}$ & $\begin{array}{l}2395 \\
(100)\end{array}$ & 0.203 & 0.652 \\
\hline $\begin{array}{l}\text { Impaired } \\
\text { vision }\end{array}$ & $\begin{array}{l}583 \\
(38.2)\end{array}$ & $\begin{array}{l}605 \\
(32.3)\end{array}$ & $\begin{array}{l}4644 \\
(100)\end{array}$ & & \\
\hline Poor vision & $\begin{array}{l}667 \\
(43.7)\end{array}$ & $\begin{array}{l}886 \\
(47.3)\end{array}$ & $\begin{array}{l}5573 \\
(100)\end{array}$ & & \\
\hline \multicolumn{6}{|c|}{ Right refracted Pre-op } \\
\hline Good vision & $\begin{array}{l}546 \\
(35.8)\end{array}$ & $\begin{array}{l}491 \\
(26.2)\end{array}$ & $\begin{array}{l}3180 \\
(100)\end{array}$ & 2.160 & 0.141 \\
\hline $\begin{array}{l}\text { Impaired } \\
\text { vision }\end{array}$ & $\begin{array}{l}462 \\
(30.3)\end{array}$ & $\begin{array}{l}434 \\
(23.2)\end{array}$ & $\begin{array}{l}2586 \\
(100)\end{array}$ & & \\
\hline Poor vision & $\begin{array}{l}187 \\
(12.2)\end{array}$ & $\begin{array}{l}137 \\
(7.3)\end{array}$ & $\begin{array}{l}1084 \\
(100)\end{array}$ & & \\
\hline \multicolumn{6}{|c|}{ Left refracted Pre-op } \\
\hline Good vision & $\begin{array}{l}485 \\
(31.8)\end{array}$ & $\begin{array}{l}441 \\
(23.6)\end{array}$ & $\begin{array}{l}3035 \\
(100)\end{array}$ & 0.915 & 0.338 \\
\hline $\begin{array}{l}\text { Impaired } \\
\text { vision }\end{array}$ & $\begin{array}{l}495 \\
(32.4)\end{array}$ & $\begin{array}{l}438( \\
23.4)\end{array}$ & $\begin{array}{l}2583 \\
(100)\end{array}$ & & \\
\hline Poor vision & $\begin{array}{l}210 \\
(13.8)\end{array}$ & $\begin{array}{l}162 \\
(8.7)\end{array}$ & $\begin{array}{l}1132 \\
(100)\end{array}$ & & \\
\hline
\end{tabular}

Chi Square for Trend and its $p$ value calculated for "Good vision" vs "Others"

$* * * \mathrm{P}$ value significant $<0.05$

The number and percentage of reported cataract operations by year and post-operation visual acuity is illustrated by Table 7. There were significant increases in trends of percentage of good vision among reported cataract operations ( $p$ value $<0.05$; Table 7) for right unaided post-operation (14.9\% of total cataract operations in 2007 to $27.2 \%$ of total cataract operations in 2014); left unaided post-operation (15.7\% of total cataract operations in 2007 to $23.1 \%$ of total cataract operations in 2014); right refracted post-operation $(29.2 \%$ of total cataract operations in 2007 to $40.0 \%$ of total cataract operations in 2014) and left refracted post-operation (31.8\% of total cataract operations in 2007 to $36.1 \%$ of total cataract operations in 2014).
Table 7. Number and percentage of reported cataract operations by year and post-operation visual acuity, Hospital Melaka, 2007-2014

\begin{tabular}{|c|c|c|c|c|c|}
\hline & $\begin{array}{l}2007 \\
\text { N (\%) }\end{array}$ & $\begin{array}{l}2014 \\
\text { N (\%) }\end{array}$ & $\begin{array}{l}\text { Total } \\
2007- \\
2014 \\
\text { N (\%) }\end{array}$ & $\begin{array}{l}\text { Chi } \\
\text { Square } \\
\text { for } \\
\text { Trend }^{\sim}\end{array}$ & P value \\
\hline Total & $\begin{array}{l}1527 \\
(100)\end{array}$ & $\begin{array}{l}1872 \\
(100)\end{array}$ & $\begin{array}{l}12992 \\
(100)\end{array}$ & & \\
\hline
\end{tabular}

Right unaided Post-op

\begin{tabular}{llll} 
Good vision & 227 & 509 & 2801 \\
& $(14.9)$ & $(27.2)$ & $(100)$ \\
\hline Impaired & 342 & 338( & 2684 \\
vision & $(22.4)$ & $18.1)$ & $(100)$ \\
Poor vision & 149 & $66(3.5)$ & 744 \\
& $(9.8)$ & & $(100)$
\end{tabular}

Left unaided Post-op

$\begin{array}{llllll}\text { Good vision } & 239 & 432 & 2625 & 79.579 & \mathrm{P}<0.001 * * * \\ & (15.7) & (23.1) & (100) & & \\ \text { Impaired } & 370 & 349 & 2621 & \\ \text { vision } & (24.2) & (18.6) & (100) \\ \text { Poor vision } & 133 & 93(5) & 751 \\ & (8.7) & & (100)\end{array}$

Right refracted Post-op

$\begin{array}{llllll}\text { Good vision } & 446 & 748 & 4694 & 66.251 & \mathrm{P}<0.001^{* * *} \\ & (29.2) & (40.0) & (100) & & \\ & & & \end{array}$

Impaired $\quad 145(\quad 69(3.7) \quad 672$

vision 9.5$) \quad(100)$

$\begin{array}{llll}\text { Poor vision } & 38 & 27(1.4) \quad 237\end{array}$

Left refracted Post-op

\begin{tabular}{|c|c|c|c|c|c|}
\hline Good vision & $\begin{array}{l}485 \\
(31.8)\end{array}$ & $\begin{array}{l}676 \\
(36.1)\end{array}$ & $\begin{array}{l}4515 \\
(100)\end{array}$ & 43.753 & $P<0.001^{* * *}$ \\
\hline $\begin{array}{l}\text { Impaired } \\
\text { vision }\end{array}$ & $\begin{array}{l}144 \\
(9.4)\end{array}$ & $88(4.7)$ & $\begin{array}{l}634 \\
(100)\end{array}$ & & \\
\hline Poor vision & $\begin{array}{l}39 \\
(2.6)\end{array}$ & 35 (1.9) & $\begin{array}{l}265 \\
(100)\end{array}$ & & \\
\hline
\end{tabular}

Chi Square for Trend and its P value calculated for "Good vision" vs "Others"

$* * * \mathrm{P}$ value significant $<0.05$

Table 8 provides the number and percentage of reported cataract operations by year and types of surgery operation and selected surgical parameters. There was significant increase in trend of percentage of Phaco among reported cataract operations ( $p$ value $<0.05$ ) rising from $75.4 \%$ in 2007 to $89.8 \%$ in 2014 . This rise was accompanied by the significant reduction in trend of percentage of ECCE among reported cataract operations ( $p$ value $<0.05$; Table 8 ) from $20.1 \%$ in 2007 to $16.2 \%$ in 2014.

With regards to surgeon status, there was an increase in involvement of Specialists as the surgeon involved in the cataract operations, rising from $72.8 \%$ in 2007 to $92.3 \%$ in 2014 ( $p$ value $<0.001$; Table 8 ). This rise was accompanied by the significant reduction in trend of percentage of Medical Officers involved in cataract operations from $12.9 \%$ in 2007 to $7.5 \%$ in 2014. 
Table 8. Number and percentage of reported cataract operations by year, types of surgery and selected surgical parameters, Hospital Melaka, 2007-2014

\begin{tabular}{|c|c|c|c|c|c|}
\hline & $\begin{array}{l}2007 \\
\text { N (\%) }\end{array}$ & $\begin{array}{l}2014 \\
N(\%)\end{array}$ & $\begin{array}{l}\text { Total } \\
2007- \\
2014 \\
\text { N (\%) }\end{array}$ & $\begin{array}{l}\text { Chi Square } \\
\text { for Trend }\end{array}$ & $P$ value \\
\hline Total & $\begin{array}{l}1527 \\
(100)\end{array}$ & $\begin{array}{l}1872 \\
(100)\end{array}$ & $\begin{array}{l}12992 \\
(100)\end{array}$ & & \\
\hline \multicolumn{6}{|c|}{ Types of surgery } \\
\hline ECCE & $\begin{array}{l}307 \\
(20.1)\end{array}$ & $\begin{array}{l}132 \\
(7.1)\end{array}$ & $\begin{array}{l}2000 \\
(100)\end{array}$ & $63.744^{\#}$ & $\mathrm{P}<0.001 * * *$ \\
\hline ICCE & $10(0.7)$ & $11(0.6)$ & $78(100)$ & & \\
\hline $\begin{array}{l}\text { Lens aspi- } \\
\text { ration }\end{array}$ & $25(1.6)$ & $16(0.9)$ & $\begin{array}{l}161 \\
(100)\end{array}$ & & \\
\hline Phaco & $\begin{array}{l}1151 \\
(75.4)\end{array}$ & $\begin{array}{l}1681 \\
(89.8)\end{array}$ & $\begin{array}{l}10497 \\
(100)\end{array}$ & $81.692^{\sim}$ & $\mathrm{P}<0.001 * * *$ \\
\hline $\begin{array}{l}\text { Phaco } \\
\text { converted } \\
\text { to ECCE }\end{array}$ & $24(1.6)$ & $28(1.5)$ & $\begin{array}{l}185 \\
(100)\end{array}$ & & \\
\hline Others & $0(0)$ & $4(0.2)$ & $45(100)$ & & \\
\hline \multicolumn{6}{|c|}{ Surgeon status } \\
\hline $\begin{array}{l}\text { Gazetting } \\
\text { Specialist }\end{array}$ & $\begin{array}{l}216 \\
(14.1)\end{array}$ & $3(0.2)$ & $\begin{array}{l}759 \\
(100)\end{array}$ & & \\
\hline $\begin{array}{l}\text { Medical } \\
\text { Officer }\end{array}$ & $\begin{array}{l}197 \\
(12.9)\end{array}$ & $\begin{array}{l}140 \\
(7.5)\end{array}$ & $\begin{array}{l}1498 \\
(100)\end{array}$ & $133.448^{s}$ & $\mathrm{P}<0.001 * * *$ \\
\hline Specialist & $\begin{array}{l}1112 \\
(72.8)\end{array}$ & $\begin{array}{l}1728 \\
(92.3)\end{array}$ & $\begin{array}{l}10720 \\
(100)\end{array}$ & $688.050^{\S}$ & $\mathrm{P}<0.001 * * *$ \\
\hline \multicolumn{6}{|c|}{ Type of anaesthesia } \\
\hline General & $55(3.6)$ & $43(2.3)$ & $\begin{array}{l}503 \\
(100)\end{array}$ & 0.473 & 0.491 \\
\hline Local & $\begin{array}{l}1470 \\
(96.3)\end{array}$ & $\begin{array}{l}1809 \\
(96.6)\end{array}$ & $\begin{array}{l}12430 \\
(100)\end{array}$ & & \\
\hline \multicolumn{6}{|c|}{ Surgery done with: } \\
\hline $\begin{array}{l}\text { Pterygium } \\
\text { surgery }\end{array}$ & $2(0.1)$ & $3(0.2)$ & $\begin{array}{l}23 \\
(100)\end{array}$ & 0.072 & 0.788 \\
\hline No & $\begin{array}{l}1525 \\
(99.9)\end{array}$ & $\begin{array}{l}1869 \\
(99.8)\end{array}$ & $\begin{array}{l}12969 \\
(100)\end{array}$ & & \\
\hline $\begin{array}{l}\text { Filtering } \\
\text { surgery }\end{array}$ & $26(1.7)$ & $13(0.7)$ & $\begin{array}{l}164 \\
(100)\end{array}$ & 23.639 & $\mathrm{P}<0.001 * * *$ \\
\hline No & $\begin{array}{l}1501 \\
(98.3)\end{array}$ & $\begin{array}{l}1859 \\
(99.3)\end{array}$ & $\begin{array}{l}12828 \\
(100)\end{array}$ & & \\
\hline $\begin{array}{l}\text { Vitreo-reti- } \\
\text { nal surgery }\end{array}$ & $27(1.8)$ & $9(0.5)$ & $\begin{array}{l}102 \\
(100)\end{array}$ & 28.164 & $\mathrm{P}<0.001 * * *$ \\
\hline No & $\begin{array}{l}1500 \\
(98.2)\end{array}$ & $\begin{array}{l}1863 \\
(99.5)\end{array}$ & $\begin{array}{l}12890 \\
(100)\end{array}$ & & \\
\hline
\end{tabular}

"Chi Square for Trend and its P value calculated for "ECCE" vs "Others" "Chi Square for Trend and its P value calculated for "Phaco" vs "Others" sChi Square for Trend and its P value calculated for "Specialist" vs "Others"

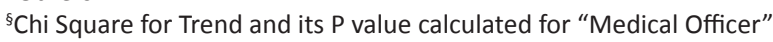
vs "Others"

$* * *$ P value significant $<0.05$

There were significant reductions in trends when the surgery was combined with filtering surgery reducing from $1.7 \%$ of total cataract operations in 2007 to $0.7 \%$ in 2014 and vitreo-retinal surgery from $1.8 \%$ of total cataract operations in 2007 to $0.5 \%$ in 2014 ( $p$ value < 0.001; Table 8).
Table 9. Number and percentage of reported cataract operations by year, site of wound and intra-op complications, Hospital Melaka, 2007-2014

\begin{tabular}{|c|c|c|c|c|c|}
\hline & $\begin{array}{l}2007 \\
N(\%)\end{array}$ & $\begin{array}{l}2014 \\
\text { N (\%) }\end{array}$ & $\begin{array}{l}\text { Total } \\
2007- \\
2014 \\
\text { N (\%) }\end{array}$ & $\begin{array}{l}\text { Chi } \\
\text { Square } \\
\text { for } \\
\text { Trend }\end{array}$ & $P$ value \\
\hline Total & $\begin{array}{l}1527 \\
(100)\end{array}$ & $\begin{array}{l}1872 \\
(100)\end{array}$ & $\begin{array}{l}12992 \\
(100)\end{array}$ & & \\
\hline \multicolumn{6}{|l|}{ Site of wound } \\
\hline Corneal & $0(0)$ & $\begin{array}{l}1565 \\
(83.6)\end{array}$ & $\begin{array}{l}3552 \\
(100)\end{array}$ & $2.236^{\#}$ & 0.132 \\
\hline Limbal & $0(0)$ & $\begin{array}{l}94 \\
(5.0)\end{array}$ & $\begin{array}{l}278 \\
(100)\end{array}$ & & \\
\hline Scleral & $0(0)$ & $\begin{array}{l}176 \\
(9.4)\end{array}$ & $\begin{array}{l}357 \\
(100)\end{array}$ & & \\
\hline \multicolumn{6}{|c|}{ Intra-op complication } \\
\hline $\begin{array}{l}\text { Post capsule } \\
\text { rupture }\end{array}$ & $88(5.8)$ & $\begin{array}{l}69 \\
(3.7)\end{array}$ & $\begin{array}{l}623 \\
(100)\end{array}$ & 19.979 & $\mathrm{P}<0.001^{* * *}$ \\
\hline No & $\begin{array}{l}1439 \\
(94.2)\end{array}$ & $\begin{array}{l}1803 \\
(96.3)\end{array}$ & $\begin{array}{l}12369 \\
(100)\end{array}$ & & \\
\hline Vitreous loss & $47(3.1)$ & $\begin{array}{l}36 \\
(1.9)\end{array}$ & $\begin{array}{l}411 \\
(100)\end{array}$ & 16.447 & $\mathrm{P}<0.001 * * *$ \\
\hline No & $\begin{array}{l}1480 \\
(96.9)\end{array}$ & $\begin{array}{l}1836 \\
(98.1)\end{array}$ & $\begin{array}{l}12581 \\
(100)\end{array}$ & & \\
\hline $\begin{array}{l}\text { Zonular dehis- } \\
\text { cence }\end{array}$ & $32(2.1)$ & $\begin{array}{l}15 \\
(0.8)\end{array}$ & $\begin{array}{l}146 \\
(100)\end{array}$ & 16.619 & $\mathrm{P}<0.001 * * *$ \\
\hline No & $\begin{array}{l}1495 \\
(97.9)\end{array}$ & $\begin{array}{l}1857 \\
(99.2)\end{array}$ & $\begin{array}{l}12846 \\
(100)\end{array}$ & & \\
\hline $\begin{array}{l}\text { Dropped } \\
\text { nucleus }\end{array}$ & $0(0)$ & $2(0.1)$ & $\begin{array}{l}17 \\
(100)\end{array}$ & 0.952 & 0.329 \\
\hline No & $\begin{array}{l}1527 \\
(100)\end{array}$ & $\begin{array}{l}1870 \\
(99.9)\end{array}$ & $\begin{array}{l}12975 \\
(100)\end{array}$ & & \\
\hline $\begin{array}{l}\text { Suprachoroi- } \\
\text { dal h'gge }\end{array}$ & $1(0.1)$ & $0(0)$ & $5(100)$ & 5.374 & $0.020 * * *$ \\
\hline No & $\begin{array}{l}1526 \\
(99.9)\end{array}$ & $\begin{array}{l}1872 \\
(100)\end{array}$ & $\begin{array}{l}12987 \\
(100)\end{array}$ & & \\
\hline
\end{tabular}

\#Chi Square for Trend and its P value calculated for "Corneal" vs "Others"

*** $\mathrm{P}$ value significant $<0.05$

There were no significant differences in trends of percentage of total cataract operations ( $p$ value $>0.05$; Table 5 ) with regards to the use of general anaesthesia $(2.3 \%$ of total cataract operations in 2014) and local anaesthesia (96.6\% of total cataract operations in 2014).

Table 9 shows the number and percentage of reported cataract operations by year and site of wound and intraoperation complications. In 2014, the site of wound was noted at corneal with $83.6 \%$ of total cataract operations, limbal at $5.0 \%$ of total cataract operations and scleral at $9.4 \%$ of total cataract operations.

There were significant reductions in trends of percentage of intra-operation complications ( $p$ value $<0.001$; Table 9) among reported cataract operations such as PCR $(5.8 \%$ of total cataract operations in 2007 to $3.7 \%$ of total cataract operations in 2014); vitreous loss (3.1\% of total cataract operations in 2007 to $1.9 \%$ of total cataract operations 
in 2014); zonular dehiscence $(2.1 \%$ of total cataract operations in 2007 to $0.8 \%$ of total cataract operations in 2014) and suprachoroidal hemorrhage $(0.1 \%$ of total cataract operations in 2007 to $0.0 \%$ of total cataract operations in 2014).

The number and percentage of reported IOLs by year and anatomical position, IOL material and type of lens (foldable/rigid) is shown in Table 10. With regards to

Table 10. Number and percentage of reported cataract

operations by year, anatomical position of IOL, IOL material and type of IOL, Hospital Melaka, 2007-2010

\begin{tabular}{|c|c|c|c|c|c|}
\hline & $\begin{array}{l}2007 \\
\text { N (\%) }\end{array}$ & $\begin{array}{l}2014 \\
\text { N (\%) }\end{array}$ & $\begin{array}{l}\text { Total } \\
2007- \\
2014\end{array}$ & $\begin{array}{l}\text { Chi } \\
\text { Square } \\
\text { for Trend }\end{array}$ & P value \\
\hline Total & $\begin{array}{l}1527 \\
(100)\end{array}$ & $\begin{array}{l}1872 \\
(100)\end{array}$ & $\begin{array}{l}12992 \\
(100)\end{array}$ & & \\
\hline
\end{tabular}

Anatomical position of $\mathrm{IOL}$

\begin{tabular}{llllll|}
$\begin{array}{l}\text { Anterior } \\
\text { chamber }\end{array}$ & 31 & 12 & 170 & $33.917^{5}$ & $\mathrm{P}<0.001^{* * *}$ \\
\hline $\begin{array}{l}\text { Posterior } \\
\text { chamber }\end{array}$ & 1448 & 1817 & 12429 & & \\
\hline Scleral fixated & $(94.8)$ & $(97.1)$ & $(100)$ & & \\
& 13 & $3(0.2)$ & 55 \\
& $(0.9)$ & & $(100)$ &
\end{tabular}

Intraocular material

\begin{tabular}{|llllll|}
\hline Acrylic & 1193 & 1717 & 10661 & $161.197^{\#}$ & $\mathrm{P}<0.001^{* * *}$ \\
& $(78.1)$ & $(91.7)$ & $(100)$ & & \\
\hline PMMA & 300 & $112(6)$ & 2021 & & \\
& $(19.6)$ & & $(100)$ & & \\
Silicone & $6(0.4)$ & $0(0)$ & $\begin{array}{l}53 \\
(100)\end{array}$ &
\end{tabular}

Type of lens

\begin{tabular}{llllll} 
Foldable & 1202 & 1704 & 10662 & 99.412 & $P<0.001^{* * *}$ \\
& $(18.8)$ & $(7.3)$ & $(100)$ & & \\
\hline Rigid & $287(0)$ & $136(0)$ & 2067 & &
\end{tabular}

\section{Poor Outcomes}

$\begin{array}{llllll}\text { High astigma- } & 70 & 23 & 175 & 68.921 & \mathrm{P}<0.001^{* * *}\end{array}$

$\begin{array}{llll}\text { tism } & (4.6) & (1.2) & (100) \\ \text { No } & 1457 & 1849 & 12817\end{array}$

No $\quad \begin{array}{llll}1457 & 1849 & 12817\end{array}$

$\begin{array}{llllll} & (95.4) & (98.8) & (100) & & \\ \text { Posterior cap- } & 22 & 3(0.2) & 70 & 19.943 & \mathrm{P}<0.001^{* * *}\end{array}$

$\begin{array}{lllll}\text { sule opacity } & (1.4) & & (100) & \\ \text { No } & 1505 & 1869 & 12922 & \end{array}$

\begin{tabular}{llll} 
No & 1505 & 1869 & 12922 \\
& $(98.6)$ & $(99.8)$ & $(100)$ \\
\hline
\end{tabular}

\begin{tabular}{llllll|}
$\begin{array}{llll}\text { Cystoid macu- } \\
\text { lar edema }\end{array}$ & $\begin{array}{l}27 \\
(1.8)\end{array}$ & $2(0.1)$ & $\begin{array}{l}54 \\
(100)\end{array}$ & 42.324 & $\mathrm{P}<0.001^{* * *}$ \\
\hline No & 1500 & 1870 & $\begin{array}{l}12938 \\
(100)\end{array}$ & & \\
& $(98.2)$ & $(99.9)$ & & \\
$\begin{array}{l}\text { Infective endo- } \\
\text { phthalmitis }\end{array}$ & $0(0)$ & $0(0)$ & $3(100)$ & 1.438 & 0.230 \\
No & 1527 & 1872 & 12989 & & \\
& $(100)$ & $(100)$ & $(100)$ & & \\
\hline
\end{tabular}

"PMMA - Polymethylmethacrylate

"Chi Square for Trend and its P value calculated for "Acrylic" vs "Others"

sChi Square for Trend and its P value calculated for "Anterior chamber" vs "Others"

***P value significant $<0.05$ anatomical position, anterior chamber lenses (ACIOL) placement reduced from $2.0 \%$ of total IOLs in 2007 to $0.6 \%$ of total IOLs in $2014(\mathrm{P}<0.001)$ while scleral fixated diminished from $0.9 \%$ in 2007 to $0.2 \%$ in 2014 ( $p$ value < 0.05; Table 10).

As for type of lens, we observed a reduction in percentage of the foldable type from $18.8 \%$ of total cataract operations in 2007 to $7.3 \%$ of total cataract operations in 2014 ( $p$ value $<0.05$; Table 10).

We observed significant reductions in trend of percentage of poor outcomes ( $p$ value $<0.001$; Table 11) among reported cataract operations such as high astigmatism (4.6\% of total cataract operations in 2007 to $1.2 \%$ of total cataract operations in 2014; posterior capsule opacity (1.4\% of total cataract operations in 2007 to $0.2 \%$ of total cataract operations in 2014) and cystoid macular edema (1.8\% of total cataract operations in 2007 to $0.1 \%$ of total cataract

Table 11. Number and percentage of reported cataract operations by post-operative outcomes, Hospital Melaka, 20072010

\begin{tabular}{|c|c|c|c|c|c|}
\hline & 2007 N (\%) & $\begin{array}{l}2014 \mathrm{~N} \\
\text { (\%) }\end{array}$ & $\begin{array}{l}\text { Total } \\
2007- \\
2014 \\
\text { N (\%) }\end{array}$ & $\begin{array}{l}\text { Chi } \\
\text { Square } \\
\text { for } \\
\text { Trend }\end{array}$ & $P$ value \\
\hline Total & $1527(100)$ & $\begin{array}{l}1872 \\
(100)\end{array}$ & $\begin{array}{l}12992 \\
(100)\end{array}$ & & \\
\hline
\end{tabular}

Post-operative Outcomes

$\begin{array}{lllll}\text { High astig- } 70(4.6) \quad 23(1.2) & 175 \quad 68.921 & P<0.001^{* * *}\end{array}$

matism

$\begin{array}{lllllll}\text { No } & 1457(95.4) & 1849 & 12817 & & \\ & & (98.8) & (100) & & \\ \text { Posterior } & 22(1.4) & 3(0.2) & 70 & 19.943 & \text { P<0.001*** }\end{array}$

$\begin{array}{lll}22(1.4) & 3(0.2) \quad 70\end{array}$

capsule (100)

opacity

\begin{tabular}{|llllll|}
\hline No & $1505(98.6)$ & $\begin{array}{l}1869 \\
(99.8)\end{array}$ & $\begin{array}{l}12922 \\
(100)\end{array}$ & & \\
\hline $\begin{array}{l}\text { Cystoid } \\
\text { macular } \\
\text { edema }\end{array}$ & $27(1.8)$ & $2(0.1)$ & $\begin{array}{l}54 \\
(100)\end{array}$ & 42.324 & P<0.001*** \\
\hline No & $1500(98.2)$ & $\begin{array}{l}1870 \\
(99.9)\end{array}$ & $\begin{array}{l}12938 \\
(100)\end{array}$ & & \\
\hline $\begin{array}{l}\text { Infective } \\
\text { endo- } \\
\text { phthal- } \\
\text { mitis }\end{array}$ & $0(0)$ & $0(0)$ & 3 & 1.438 & 0.230 \\
\hline No & $1527(100)$ & 1872 & 12989 & & \\
& & $(100)$ & $(100)$ & & \\
\hline
\end{tabular}

"PMMA - Polymethylmethacrylate

"Chi Square for Trend and its P value calculated for "Acrylic" vs "Others"

SChi Square for Trend and its P value calculated for "Anterior chamber" vs "Others"

***P value significant $<0.05$ operations in 2014). 


\section{DISCUSSION}

We conducted this study with the aim of studying the trends of cataract surgery in our set-up which is a Public Center for cataract services in the state using the NED to see if we are moving towards our goal of eradicating blindness due to cataract.

Most of our patients were aged 60 to 69 years (38.7\% of total patients) with more being females (53.0\%). Majority were Malays (47.8\%) followed by Chinese (38.2\%) and the Indians (12.4\%).

Similar findings were seen in a study in Temerloh Hospital Malaysia where most patients were $61,60,70$ years $(40.5 \%)$ followed by 71 to 80 yeas (26.8\%) and 51 to 60 (21.4\%). Majority were Malays (65.9\%) followed by Chinese (21.8\%) and Indians (11.8\%). The gender distribution in Temerloh did not vary with 50.3 Males and 49.3 Females undergoing surgery. ${ }^{5}$

Phacoemulsification was the commonest type of surgery (80.8\%). Elsewhere in Malaysia in Temerloh Hospital, Phacoemulsification was the commonest (61.9\%) followed by ECCE (31.9\%) and Phaco converted to ECCE (3.9\%). ${ }^{5}$ In Singapore 99\% of cataract surgeons preferred phacoemulsification compared to other techniques. ${ }^{6}$

Complications occurred in $7 \%$ of surgeries, the commonest of which was PCR( $4.8 \%$ ) followed by vitreous loss (3.2\%), Other studies also noted that PCR was the commonest complication followed by vitreous loss. ${ }^{7-9}$

We found a rise in primary senile cataracts. Senile cataracts (93.4\%) constituted the majority of cataract operations in the profile of patients presenting for cataract surgery in Malaysia. ${ }^{10}$

In our Center, presence of Hypertension and Diabetes increased over the years among our cataract surgery patients. The Malaysian cataract registry report states that a high percentage of patients undergoing cataract surgery presented with hypertension (48.9\%) and diabetes mellitus $(37.1 \%){ }^{10}$ The rise in number of patients presenting to us with Diabetes and Hypertension for cataract surgery correlates with the rise in the number of patients who have these systemic illnesses. An audit of Diabetes control and Management in 2009 found 57.4\% having Hypertension and $97.2 \%$ with Type 2 Diabetes. The National Diabetes Registry 2012 reports $70.1 \%$ having Hypertension and $100.0 \%$ having Diabetes. ${ }^{11}$

We did not find any change with regards to laterality $(p<0.05)$ or whether the first or second eye was operated on $(p<0.05)$. However, the Malaysian cataract surgery registry report states that one third had second eye surgery. ${ }^{10}$

In our series, the only ocular comorbidity of patients undergoing cataract surgery showing a rise was pterygia encroaching onto the cornea. Nam et al. in a study of 16,234 adults in South Korea, observed that prevalence of pterygium tended to increase with a rise in Body Mass Index in women. In addition, the rise was also noted in both men and women with increased waist circumference..$^{12}$ Ismail et al. found that the escalation of obesity, once thought to be an urban phenomenon, has now spread to the rural population at an alarming rate in Malaysia. ${ }^{13}$ We postulate that there may be a rise in patients presenting with pterygium due to the increase in obesity rates. We hope that measures taken to reduce obesity will also reduce the incidence of pterygia. There was reduction in Glaucoma, PDR and VH among our cataract patients.

Although there was no difference in the preoperative vision, the postoperative visual outcomes showed improvement which is the goal of cataract surgery. The Malaysian cataract registry reported decreasing number of eyes presenting with worse than 3/60 vision. ${ }^{10}$ More Specialists were operating while the number of Medical Officers operating decreased. Trainees in Malaysia master ECCE before embarking onto phacoemulsification. This can explain why there was an increase in phacoemulsification and a decline in ECCE, as more number of trained personnel (Specialists) operated. The Malaysian Cataract registry also found a steep rise in phacoemulsification cataract surgery from $39.7 \%$ in 2002 to $78.0 \%$ in 2011 with a corresponding fall in extracapsular cataract extraction from $54.0 \%$ to $17.3 \%$ in the respective years. ${ }^{14}$

The only combination surgeries done with cataract surgery in our center were filtering surgery and vitreo-retinal surgery. Both of these showed a decline over the years. In our center, vitreo-retinal surgery was done under General Anaesthesia, and hence it was combined with cataract so that the patient does not undergo repeated GA. Mahapatra and Rao noted that combined cataract and vitreo-retinal surgery with IOL implant is a safe option reducing the need for combined surgery in patients with intraocular foreign body and cataract. ${ }^{15}$ Moreover, Yuen et al. found no difference in surgically induced Astigmatism whether cataract and vitreo-retinal surgeries were done separately or in combination. ${ }^{16}$ The commonest combination surgery in the Malaysian Cataract Registry was also cataract combined with vitreo-retinal surgery. ${ }^{14}$

The type of anaesthesia used did not change. However, a study on trends of local anaesthesia in the same hospital found that there was a rise in the use of topical anaesthesia and $a$ fall in the use of subtenon anaesthesia. ${ }^{17}$ General anaesthesia use was minimal as it is used for children, uncooperative patients and for those who request it for cataract surgeries.

The anatomical location of the wound was unchanged though most of the wounds were corneal. Histological evidence has shown that limbal wounds had an early fibroblastic response and therefore healed earlier compared to corneal wounds. ${ }^{18}$ Kershne found that visual recovery occurred within 24 hours after clear corneal 
incisions. ${ }^{19}$ It is important to get a water tight wound in cataract surgery to prevent wound leakage, hypotony and the ingress of microorganisms which could lead to infection. Masket and Belani reported that square-shaped clear corneal wounds that are meticulously checked for sealing were stable postoperatively as demonstrated by the absence of hypotony and wound leakage. ${ }^{20}$ Our usual practice is sutureless corneal incisions, but even if there is a micro leak, we suture the wound. Thomas et al. 21 reported culture positive endophthalmitis in the unsutured group and none in the sutured group of clear corneal incisions $(p<0.05) .{ }^{21}$ Therefore it is a good practice that we do in suturing our wounds with microleak.

The reduced number of intraoperative complications could be explained by the fact that more Specialists were operating and had more experience in cataract surgery, which lead to fewer intraoperative complications over the years. Another explanation could also be that more Specialists were available to closely monitor trainees. Thomas et al. found that the surgical complications for residents learning phaco can be low with close monitoring..$^{22}$ Thanigasalam et al. found that phaco was associated with fewer complications, and perhaps that could also explain the drop in intraoperative complications with the increase in phaco cases. ${ }^{23}$

The drop in use of ACIOL and scleral fixated IOLs correlates with the drop in intraoperative complications such as PCR and vitreous loss as a PCIOL could be placed with adequate posterior capsule support. Studies have shown no difference in long term complications between $\mathrm{AClOL}$ and scleral fixated IOLs. ${ }^{24,25}$ Therefore the use of both types of lenses are acceptable.

The rise in the number of phaco cases should have seen a rise in the use of foldable IOLs. However, we observed a downward trend in the use of foldable IOLs. One reason is that the cost of a foldable IOL is more and there were many patients who requested for cheaper lenses and hence; were given non-foldable IOLs. This of course needed a larger wound and sutures to be placed. The cost of sutures is borne by the hospital and sutures cause Astigmatism. In Malaysia, a study published in 2004 states that conventional extracapsular cataract surgery with intraocular lens implant costs RM3442 (USD 905.79) and phacoemulsification with intraocular lens implant costs RM4288 (USD 1128.42). ${ }^{26}$ Further studies should be done to evaluate the cost effectiveness and outcomes of phaco with foldable and non-foldable IOLs.

Postoperative poor visual outcomes and complications such as high astigmatism, PCO and CME reduced. The reduction in poor outcomes is in line with the goal of cataract surgery which is to improve visual outcomes. Thanigasalam et al found that the main reasons for the poorer outcomes were high astigmatism, CME, and corneal decompensation. ${ }^{27}$ Our patients had better outcomes as there was reduction in high astigmatism and CME. The reduction in PCR could also account for the reduced poor outcome. Thevi and Sahoo found that phaco cases with PCR were significantly less likely to have good vision compared to those without PCR (OR 0.335; 95\% Cl 0.157-0.714). ${ }^{28}$ However, another study on PCR with or without vitreous loss among phacoemulsification found an improvement in vision postoperatively and none had poor vision. ${ }^{29}$ Thanigasalam et al. found that the type of surgery affected the visual improvement $(p<0.001)$ and phaco patients had good outcomes. ${ }^{5}$ The rise in phaco and use of foldable intraocular lenses could also explain the reduction in poor outcomes. This is supported by a study which found uncomplicated phacos with intraocular lenses giving good results. ${ }^{30}$

The total number of surgeries done over 8 years in Melaka Hospital was 12,992 (round up 13,000 cases a year). This averages to 1,625 cases per year. The annual incidence rate of cataract surgery reduced from 2.05 per 1000 population in 2007 to 2.02 per 1000 population in $2010(p<0.05) .^{31}$ We are unable to compare the incidence rates of cataract surgeries done among the population in other states as they have not been published yet.

The National Eye Survey 11 found that the estimated number of cataract blind eyes (corrected vision 6/60) in the Southern zone (Melaka and Johor) for those aged 50 years and above was $32,204 . .^{32} \mathrm{~A}$ sample size of 2500 (50 clusters of size 50) was adequate enough to estimate a prevalence of blindness of $4.0 \%$ in people aged 50 and above with an interval of $3.0-5.0 \%$, a confidence level of $95 \%$ and $90 \%$ compliance in each zone.

The survey found that barriers to treatment included need not felt $(20 \%)$, fear $(20 \%)$, cost $(20 \%)$, unaware that treatment is possible $(10 \%){ }^{32}$ We have to overcome barriers to cataract surgeries treatment by educating and counselling the public. This can be achieved by public health programs and talks at the ground level by a dedicated team involving Ophthalmologists, Public Health Specialists, Family Physicians and Allied Health personnel. With these measures in place, there is a possibility of getting closer to our goal of achieving vision 2020 to eliminate preventable and treatable blindness due to cataract.

As this was a study utilizing retrospective secondary data analysis, only variables incorporated within the National Eye Database could be used for analysis. In addition, the National Eye Database only covers patients attending government hospitals in the state of Melaka and does not give the true picture of the entire state as Private Hospitals in the State are not included. We do hope that in future databases would be able to include all facilities of the country for better results to be analysed. Prospective studies could give more value on other parameters to be studied and avoid missing data.

It is possible that certain confounding factors such as status of diabetic retinopathy and maculopathy were not accounted for in those with poor fundal view. CME may 
be missed without Ocular Coherence Topography (CME) to know the actual incidence. Poor outcomes of high astigmatism may have had other contributing factors such as retinopathy or maculopathy which may have not been eliminated in the data entry. PCO may not have been captured as data was entered at as early as 6 weeks postoperatively.

Despite these limitations, there is enough data to generate information pertaining to trends of cataract surgery in the largest government hospital in Melaka.

\section{CONCLUSION}

Most patients undergoing cataract surgery in our Center were 60 to 69 years with a mean age of 65.0 years with majority being Malays, followed by Chinese and Indians. More primary cataracts were operated $(p<0.05)$. In line with the advancement of cataract surgery technique, phacoemulsification was the commonest surgery and showed a rise $(p<0.05)$ with a corresponding decline in ECCE $(p<0.05)$ which was also due to the increase in Specialists operating who as experienced surgeons do more phacos $(p<0.05)$ compared to Medical Officers.

\section{REFERENCES}

1. www.who.int/blindness/Vision2020_report.pdf.Vision 2020 - World Health Organization.Accessed on 08/04/2016.

2. www.who.int/blindness/causes/.../index1.html.WHO | Priority eye diseases - World HealthOrganization, Accessed on 08/04/2016.

3. M Zainal, S M Ismail, A R Ropilah et al. Prevalence of blindness and low vision in Malaysian population: results from the National Eye Survey 1996. Br J Ophthalmol. 2002; 86(9): 951-6.

4. www.acrm.org.my/ned/ The National Eye Database (NED) accessed on $05 / 09 / 2016$.

5. Thanigasalam T, Reddy SC, Zaki RA. Factors Associated with Complications andPostoperative Visual Outcomes of Cataract Surgery; a Study of 1,632 Cases. J Ophthalmic Vis Res. 2015;10(4):375-384.

6. Tam YS, Kumar CM, Au Eong KG, Yip CC, Cheng J. Trends in Cataract Surgery Technique and Anaesthesia Preferences in Singapore: A 2016 Survey. Ann Acad Med Singap. 2018; 47(9):390-393.

7. Hasemi H, Alipour F, Rezvan F, et al. Intraoperative complications of cataract surgeries in Iran: 20002005 Iranian cataract surgery survey. Iran J Ophthalmol. 2011;23:310.

8. Ng DT, Rowe NA, Francis IC, Kappagoda MB, Haylen MJ, Schumacher RS, et al. Intraoperative complications of 1000 phacoemulsification procedures: a prospective study. I Cataract Refract Surg .1998;24(10):1390-5.

9. Thevi T, Maizura MZ. Posterior capsule rupture-causes, associations and outcomes: eight year analysis in a Malaysian General Hospital. Guoji Yanke Zazhi ( Int Eye Sci ) 2016; 16 (4):600-606.

10. Salowi MA, Goh PP, Lee MY, et al. The Malaysian Cataract Surgery Registry: Profile of Patients Presenting for Cataract Surgery. Asia Pac J Ophthalmol (Phila). 2015;4(4):191-196.

11. Chew BH, Lee PY, Cheong AT, et al. Messages from the Malaysian Diabetes Registries on Diabetes Care in Malaysian public healthcare facilities. Prim Care Diabetes. 2016;10(5):383-386.
Complications occurred in only $7 \%$ of cases, the commonest of which was PCR followed by vitreous loss.

There was a rise in systemic comorbidities of Hypertension $(p<0.05)$ and Diabetes $(p<0.05)$ which correlates with the rise in these comorbidities in our general population. The rise in pterygia encroaching the cornea $(p<0.05)$ which was the only ocular comorbidity showing a rise that may be due to the rise in obesity rates in Malaysia.

Combination surgeries declined $(p<0.001)$. We did not observe a change in local/general anaesthesia or the wound site. Intraoperative complications declined $(p<0.005)$ and this explains the reduction in the use of ACIOLs $(p<0.05)$ and scleral fixated IOLs $(p<0.05)$. Due to the drop in intraoperative complications and the rise in phacoemulsification, we saw an improvement in good visual outcomes $(p<0.05)$ and a reduction in poor visual outcomes postoperatively $(p<0.005)$ which is testament that we achieved our goal in cataract surgeries.

With the reduction observed in complication rates and the rise in good visual outcomes compared to previous years, Melaka Hospital cataract service is well on its way in contributing towards further reduction in blindness among patients with cataracts in the state of Melaka.

12. Nam GE, Kim S, Paik JS. Na KS; and the Epidemiologic Survey Committee of the Korean Ophthalmologic Society. Association between pterygium and obesity status in a South Korean population. Medicine (Baltimore) 2016;95(50):e5664.

13. Ismail MN, Chee SS, Nawawi $\mathrm{H}$, et al. Obesity in Malaysia. Obes Rev 2002;3(3):203-8.

14. Lee MY, Goh PP, Salowi MA, et al. The Malaysian Cataract Surgery Registry: Cataract Surgery Practice Pattern. Asia Pac J Ophthalmol (Phila). 2014;3(6):343-347.

15. Mahapatra SK, Rao NG. Visual outcome of pars plana vitrectomy with intraocular foreign body removal through sclerocorneal tunnel and sulcus-fixated intraocular lens implantation as a single procedure, in cases of metallic intraocular foreign body with traumatic cataract. Indian J Ophthalmol. 2010;58(2):115-8.

16. Yuen $\mathrm{CY}$, Cheung BT, Tsang CW, et al. Surgically induced astigmatism in phacoemulsification, pars plana vitrectomy, and combined phacoemulsification and vitrectomy: a comparative study. Eye (Lond). 2009;23(3):576-80.

17. Thevi T, Godinho MA. Trends and complications of local anaesthesia in cataract surgery: an 8-year analysis of 12992 patients. $\mathrm{Br} J$ Ophthalmol. 2016;100(12):1708-13.

18. Ernest $P$, Tipperman $R$, Eagle $R$, et al. Is there a difference in incision healing based on location? J Cataract Refract Surg. 1998;24(4):482-6.

19. Kershner RM. Clear corneal cataract surgery and the correction of myopia, hyperopia and astigmatism. Ophthalmology. 1997;104: 381-

20. Masket S, Belani S. Proper wound construction to prevent shortterm ocular hypotony after clear corneal incision cataract surgery. $J$ Cataract Refract Surg. 2007;33:383-6.

21. Thomas SS, Musch DC, Soong HK. Postoperative endophthalmitis associated with sutured versus unsutured clear corneal cataract incisions. Br J Ophthalmol. 2007;91:728-30. 